\title{
Compressive Strength of Concrete Using Different Curing Methods
}

\author{
Daniel Yaw Osei ${ }^{1}$, Zakari Mustapha², Mohammed D.H. Zebilila ${ }^{3}$ \\ $1 \& 3$ Civil Engineering, Cape Coast Technical University, Cape Coast, Ghana \\ ${ }^{2}$ Department of Building Technology, Cape Coast Technical University, Cape Coast, Ghana \\ mustapha.zakari.@cctu.edu.gh
}

\begin{abstract}
The structural use of concrete depends largely on its strength, especially compressive strength. Various tests were carried out to ascertain the properties of concrete materials, whereas test performances of the concrete with different mix ratios at specific ages of curing were undertaken. The study determined the compressive strength of concrete using different curing methods. Four different methods of curing (ponding, continuous wetting, open-air curing and sprinkling with water) were used. Seventy-two (72) cubes were cast using a mix ratio of $1: 2: 4$ and 1:3:6 with 0.5 water cement ratio and with 0.6 waters cement ratio respectively. The compressive strengths were determined after 7 days, 14 days and at 28 days of curing. Findings show that for 1:2:4 concrete, maximum of 28-day compressive was the highest for concrete cured by ponding and the least was by sprinkling water. Further findings show that for 1:3:6 concrete, maximum of 28-day compressive strength was obtained using ponding and the least was open air curing. Despite ponding method producing the highest compressive strength of concrete, it is practically impossible to cure cubes above ground structural elements. Wet-covering method is recommended for structural elements, such as columns, beams and slabs in other to produce concrete

of a required compressive strength.
\end{abstract}

Keywords: Control strength; compatibility; curing conditions; concrete development; concrete production.

\section{Introduction}

There are different types of curing: shading concrete work, covering concrete surfaces with hessian or gunny bags, sprinkling of water, ponding method, membrane curing and steam curing. The nature of work and climatic conditions as indicated by Padhi (2014), determines the curing method. Bushlaibi (2004) studied "the effect of curing methods on the compressive strength of silica fume high strength concrete" posited that there are five curing conditions such as: "water curing" for (28 days), "no curing", "sprinkle curing" (sprinkling two times in a day for 7days), "plastic curing" (sprinkling two times in a day with plastic cover sheet for 7 days) and "burlap curing" (sprinkling two times in a day with burlap cover for 7 days) and concluded as follows:

- "The compressive strength of the silica fume high strength concrete, as in normal strength concrete was related to curing duration".

- "The adverse effect on the development of concrete compressive strength increases with increasing temperature and test duration" and

- "The curing ages of 28 days and beyond, the strength reduction reaches up to $12 \%$ of the control strength in some curing conditions".

Several researchers' (Ogah, 2016; Padhi, 2014; Goel, et al., 2013; Raheem, et al., 2013; Bushlaibi, 2004) have different views on the suitable method of curing concrete. Out of the several curing methods suggested by Padhi (2014) and Goel, et al. (2013) "water curing" was found to be the most suitable curing method for concretes. Raheem, et al. (2013), were of the view that "moist sand" curing method was the most suitable curing method for concretes, "Drier curing" conditions was found by several researchers: Bingöl \& Tohumcu, 2013; Ferreira et al. (2012); Silva et al. (2012) to perform worse than "wet curing" conditions. Bediako et al. (2015) emphasized that the importance of curing is to primarily help cement achieve more complete hydration, whereas Jackson and Akomah, (2018), ascertained concrete needs to be cured for a maximum number of days to attain the maximum strength required. Shih-Wei Cho (2013) posited that silt with fine content of $5 \%$ and less is optimum for concrete strength and durability. The study determines the compressive strength of concrete using different curing methods. Results showed OPS concrete were in consonance with conventional lightweight concrete. 


\section{Literature Review}

Several studies on curing of recycled materials and alternative materials used in concrete production have been conducted by (Bingöl and Tohumcu, 2013; Ferreira et al., 2012; Silva et al., 2013; Mohamed, 2011; Fonseca et al., 2011; Ling and Teo, 2011; Al-Gahtani, 2010; Teo et al., 2010; Yazıcl et al., 2009; Velosa and Paulo, 2008). Silva et al. (2013) conducted a study on selected plastic waste aggregates (polyethylene terephthalate (PET) as partial replacement of course aggregate and concluded that there was a decrease in durability of concrete with plastic aggregates when compared to conventional concrete. All samples performed poorly under drier curing regimes and concrete with plastic aggregates deteriorated less under progressively drier curing conditions than conventional concrete. The volume of permeable voids (VPVs), sorptivity, water permeability, chloride diffusion coefficient and time to corrosion initiation from the 90-day salt ponding test, and Rapid Chloride Penetrability Test (RCPT) were the metrics used for the durability assessment. In another study by Ling and Teo (2011) where they determined the effect of four curing methods (full water curing, air dry curing, 3-day curing and 7-day curing) and use of waste rice husk ash (RHA) and expanded polystyrene (EPS) beads as partial replacement of cement and course aggregate respectively in lightweight concrete bricks production reported a decrease in water absorption capacity with a decrease in RHA.

Properties investigated were hardened concrete density, compressive strength and water absorption of the EPS RHA concrete bricks as well as scanning electron microscopy (SEM) analysis. Teo et al. (2010) conducted a study on oil palm shell (OPS) replaced with course aggregate under four curing conditions. Yazici et al. (2009) investigated the dependence of compressive strength, flexural strength, and toughness of reactive powder concrete (RPC) produced with class-C fly ash (FA) and ground granulated blast furnace slag (GGBFS) cured under three conditions (standard, autoclave and steam curing). An increase in compressive strength and a decrease in flexural strength and toughness were recorded under autoclave and steam curing. Increasing the GGBFS and/or FA content improved the toughness of RPC under all curing conditions. However, Fonseca et al. (2011) did not notice any difference in the compressive strength, splitting tensile strength, modulus of elasticity, and abrasion resistance of recycled aggregate concrete (RAC) and conventional concrete (CC) under different curing methods. Ferreira et al. (2012) noticed a fall in compressive and splitting tensile strength and modulus of elasticity of concrete, and increase in wear resistance to abrasion in laboratory conditions, wet chamber, and outer environment curing conditions when increasing the plastic waste replacement of course aggregates.

Bingöl and Tohumcu (2013) reported a decrease in compressive strength under air curing in a study of three curing methods (air curing, water curing and steam curing) on the compressive strength of Self Compacting Concrete (SCC) produced from silica fume (SF). For steam curing optimum performance was obtained at $70{ }^{\circ} \mathrm{C}$ for 16 hours. Mohamed (2011) reported 28 days curing having higher compressive strength than 7 days curing in a study to determine the compressive strength of self-compacting concrete (SCC) with two cement content fly ash (FA) and silica fume (SF)). This is expected since concrete strengthens with age. In BS 882 (1992) the upper allowable limit of silt content is $8 \%$ and the average silt content of sand for preparing concrete is $3.33 \%$. However, Olanitori (2012) reported a maximum value of $3 \%$ as silt content suitable for concrete production in his study. Velosa and Paulo (2008) also studied the mechanical properties and curing methods of concrete produced from hydraulic-lime binder and pozzolanic material, a residue from expanded clay production. Al-Gahtani (2010) investigated curing of Type I, silica fume, and fly ash cement concrete specimens with wet burlap covering, by applying curing water-based and acrylic-based compounds. Strength development was found to be higher with covering with wet burlap than the other two methods of curing.

\section{Methodology}

This section presents the various methods used during the laboratory experiment. The use of "Hessian sac" in the form of mulch to maintain water on the surface of the concrete cubes and it is important to ensure that all the sides of the cubes were covered (Mohamed and Najm, 2019). As soon as the concrete cubes were sufficiently hardened, wet materials were used to cover the cubes to prevent surface damage. Through the curing period, the sac was kept saturated with water. Materials used were Ordinary Portland cement, fine washed sand as fine aggregate and granite of nominal size $20 \mathrm{~mm}$ as coarse aggregate, and clean drinkable 
(pipe borne) water. Concrete mixes of $1: 2: 4$ and 1:3:6 by weights with water/cement ratio 0.5 and 0.6 respectively for the production of different types of concrete. Slump and compaction factor test done based on the BS 1881-102 and BS 1881-103 respectively, to determine the workability of the fresh concrete. Seventy-two (72) concrete cubes, as shown in Table 1 were cast and compacted, in iron - molds with internal measurement of $150 \mathrm{~mm} \times 150 \mathrm{~mm} \times 150 \mathrm{~mm}$ were used in casting the concrete cubes. Three (3) cubes each for the mix ratio $1: 2: 4$ at 0.5 water cement ratio and 1: $3: 6$ at 0.6 water cement ratio were tested after their respective curing days. All specimen from the laboratory test were used (Jackson, Mustapha, \& Kotey, 2019; Tijani and Mustapha, 2017).

Table 1: Number of Cubes for Casting and their Respective Days

\begin{tabular}{|c|c|c|c|c|c|c|}
\hline \multirow[t]{5}{*}{ Curing Method } & \multicolumn{6}{|c|}{$\begin{array}{l}\text { Number of Cubes } \\
\text { Mix Ratios }\end{array}$} \\
\hline & \multicolumn{3}{|c|}{$1: 2: 4$ at 0.5} & \multicolumn{3}{|c|}{$1: 3: 6$ at 0.6} \\
\hline & \multicolumn{3}{|c|}{ Days } & \multicolumn{3}{|c|}{ Days } \\
\hline & 7 & 14 & 28 & 7 & 14 & 28 \\
\hline & \multicolumn{3}{|c|}{ Number of cubes for each Day } & \multicolumn{3}{|c|}{ Number of cubes for each Day } \\
\hline Ponding & 3 & 3 & 3 & 3 & 3 & 3 \\
\hline Sprinkling & 3 & 3 & 3 & 3 & 3 & 3 \\
\hline Open air & 3 & 3 & 3 & 3 & 3 & 3 \\
\hline Wet covering & 3 & 3 & 3 & 3 & 3 & 3 \\
\hline
\end{tabular}

Curing Method and Test Performance: Four methods (Ponding, Sprinkling, Air Curing and Wet- covering) curing were used on concrete mix (Nahata et al., 2014; Surana et al., 2017), both in its fresh and hardened states for the experiments. The first method of curing was "Ponding". Cubes were immersed in-side water throughout the curing period and the water for the curing was maintained at an average laboratory temperature of 28C to prevent thermal stresses that could result in cracking. The second method of curing was "Sprinkling water". Sprinkling with water is an excellent method of curing when the ambient temperature is well above freezing and the humidity is low. The third method of curing was "Wet-covering". The fourth method of curing was "Totally uncured types" (open air). Throughout the curing period, concrete cubes were in the open air without any curing applied. During the Test Performance: Sieve analysis was performed on crushed granite and the fine aggregate, as prescribed in the BS 812: section 103.1: 1985. First, the performance of "Silt test" according to the BS 812 to determine the amount of silt, clay, or any other fine dust that may be present in the sand sample. Then, "Slump test", according to BS 1881-102 standard and the difference in slump in time recorded Followed by "Compaction factor test" according to BS 1881-103. This test was done to measure the degree of compaction resulting from the application of standard amount of work. Finally, the "Compressive test" was performed after a curing period of 7 days, 14 days and 28days. The cubes were loaded until failure and test was performed as prescribed in BS 1881: part 116:1983 (Neville 2010).

\section{Results and Discussion}

This section presents the results of the laboratory experiment conducted on different types of cube. Table 2 shows the average silt content as 3.33\% and this was in accordance with BS 882 (1992), with sample 2 having percentage by volume of silt depth to sand thickness and thickness of visible silt two times than the other two samples. 
Table 2: Silt Test Results (Sand)

Determination of Silt Content

Observation Sheet

\begin{tabular}{|c|c|c|c|c|}
\hline Number & Description & Sample No & & \\
\hline & & Sample $1(\mathrm{ml})$ & Sample 2 (ml) & Sample 3 (ml) \\
\hline 1 & Level of content (ml) & 150 & 150 & 150 \\
\hline 2 & $\begin{array}{l}\text { Depth of sand without silt - } \\
\text { V1 (ml) }\end{array}$ & 80 & 80 & 80 \\
\hline 3 & $\begin{array}{l}\text { Thickness of visible silt V2 } \\
\text { (ml) }\end{array}$ & 2 & 4 & 2 \\
\hline 4 & Volume of Water (ml) & 70 & 70 & 70 \\
\hline \multirow[t]{2}{*}{5} & $\begin{array}{l}\text { Percentage by volume of } \\
\text { Silt depth to sand thickness } \\
\text { (\%) } \frac{V 2}{V 1} \times 100\end{array}$ & $2.5 \%$ & $5 \%$ & $2.5 \%$ \\
\hline & Average Content & & $3.33 \%$ & \\
\hline
\end{tabular}

Compacting Factor Test and Slump Test of Concrete (1:2:4): The compacting factor test and slump test on concrete using a mix ratio 1:2:4 by weight and water/cement ratio of 0.5 shows that the slump with the highest figure of 21 had the highest compacting factor of 0.91 and the remaining two slump with a similar figures had a compacting factor difference of 0.02 . A low degree of workability from the slump and compacting factor test (Neville, 2010) were recorded from the mix.

Compacting Factor Test and Slump Test of Concrete (1:3:6): The compacting factor test and slump test on concrete using a mix ratio 1:3:6 by weight and water/cement ratio of 0.6 shows that the slump with the highest figure of 80 had the least compacting factor of 0.82 , and indicates a medium degree of workability for the concrete mix (Neville 2010). Table 3 shows the seven (7) day compressive strength test result for 1:2:4 concrete. "Ponding" had the highest average compressive strength of $17.3 \mathrm{~N} / \mathrm{mm}^{2}$, followed by "sprinkling" and the cube with least average compressive strength was "open air curing,"

Table 3: Seven (7) Day Compressive Strength

\begin{tabular}{|c|c|c|c|c|c|c|}
\hline $\begin{array}{l}\text { Name of } \\
\text { cubes }\end{array}$ & $\begin{array}{l}\text { Mass in } \\
\text { air (g) }\end{array}$ & $\begin{array}{l}\text { Mass in } \\
\text { water(g) }\end{array}$ & $\begin{array}{l}\text { Density of } \\
\text { cubes } \\
\left(\mathrm{kg} / \mathrm{cm}^{-3}\right)\end{array}$ & $\begin{array}{l}\text { Peak } \\
\text { load } \\
(\mathrm{kN})\end{array}$ & $\begin{array}{l}\text { Compressive } \\
\text { strength } \\
\left(\mathrm{N} / \mathbf{m m}^{-2}\right)\end{array}$ & $\begin{array}{l}\text { Average } \\
\text { Compressive } \\
\text { strength }\left(\mathrm{N} / \mathrm{mm}^{-2}\right)\end{array}$ \\
\hline \multicolumn{7}{|l|}{ Sprinkling } \\
\hline S1 & 8038 & 3955 & 1969 & 355.6 & 15.8 & \multirow{3}{*}{14.6} \\
\hline S1 & 7952 & 4567 & 2349 & 315.8 & 14.0 & \\
\hline S1 & 7998 & 4580 & 2340 & 316.5 & 14.1 & \\
\hline \multicolumn{7}{|l|}{ Ponding } \\
\hline P1 & 8270 & 4785 & 2373 & 406.0 & 18.0 & \multirow{3}{*}{17.3} \\
\hline P1 & 8460 & 4879 & 2362 & 404.4 & 18.0 & \\
\hline $\mathrm{P} 1$ & 8133 & 4684 & 2358 & 356.1 & 15.8 & \\
\hline \multicolumn{7}{|c|}{ Wet covering } \\
\hline W1 & 8117 & 4614 & 2317 & 287.5 & 12.8 & \multirow{3}{*}{13.6} \\
\hline W1 & 8259 & 4754 & 2357 & 310.2 & 13.8 & \\
\hline W1 & 8212 & 4751 & 2373 & 316.5 & 14.1 & \\
\hline \multicolumn{7}{|c|}{ Open air curing } \\
\hline 01 & 7923 & 4521 & 2329 & 277.8 & 12.3 & \multirow{3}{*}{12.9} \\
\hline 01 & 8095 & 4613 & 2325 & 303.0 & 13.5 & \\
\hline 01 & 7774 & 4444 & 2335 & 289.8 & 12.9 & \\
\hline
\end{tabular}




\section{Journal of Social and Development Sciences (ISSN 2221-1152)}

Vol. 10, No. 3, pp. 30-38, September 2019

Table 4 shows the 14-day compressive strength test result for 1:2:4 concrete. Ponding" had the highest average compressive strength, followed by "wet-covering" and the cube with least average compressive strength was "sprinkling."

Table 4: Fourteen (14) Day Compressive Strength

\begin{tabular}{|c|c|c|c|c|c|c|}
\hline $\begin{array}{l}\text { Name } \\
\text { cubes }\end{array}$ & $\begin{array}{l}\text { Mass in } \\
\text { air (g) }\end{array}$ & $\begin{array}{l}\text { Mass in } \\
\text { water(g) }\end{array}$ & $\begin{array}{l}\text { Density of } \\
\text { cubes } \\
\left(\mathrm{kg} / \mathrm{cm}^{-3}\right)\end{array}$ & $\begin{array}{l}\text { Peak load } \\
(\mathrm{kN})\end{array}$ & $\begin{array}{l}\text { Compressive } \\
\text { strength } \\
\left(\mathrm{N} / \mathbf{m m}^{-2}\right)\end{array}$ & $\begin{array}{l}\text { Average } \\
\text { Compressive } \\
\text { strength } \\
\left(\mathrm{N} / \mathrm{mm}^{-2}\right)\end{array}$ \\
\hline \multicolumn{7}{|c|}{ Sprinkling } \\
\hline S5 & 7961 & 4534 & 2323 & 351.8 & 15.6 & \multirow{4}{*}{15.4} \\
\hline S5 & 8083 & 4605 & 2324 & 349.0 & 15.5 & \\
\hline S5 & 7842 & 4408 & 2211 & 343.2 & 15.2 & \\
\hline \multicolumn{6}{|c|}{ Ponding } & \\
\hline P5 & 8246 & 4735 & 2468 & 414.1 & 18.4 & \multirow{3}{*}{18.4} \\
\hline P5 & 8202 & 4744 & 2475 & 431.8 & 19.2 & \\
\hline P5 & 8346 & 4682 & 2428 & 398.6 & 17.7 & \\
\hline \multicolumn{7}{|c|}{ Wet-covering } \\
\hline W5 & 8004 & 4519 & 2313 & 351.8 & 15.6 & \multirow{3}{*}{15.9} \\
\hline W5 & 7628 & 4545 & 2331 & 365.1 & 16.2 & \\
\hline W5 & 8188 & 4508 & 2306 & 355.6 & 15.8 & \\
\hline \multicolumn{7}{|c|}{ Open air curing } \\
\hline 05 & 8172 & 4720 & 2456 & 379.8 & 16.9 & \multirow{3}{*}{15.5} \\
\hline 05 & 7911 & 4550 & 2334 & 335.6 & 14.9 & \\
\hline 05 & 8117 & 4706 & 2446 & 332.2 & 14.8 & \\
\hline
\end{tabular}

Table 5 shows the twenty-eight (28) day compressive strength test result for 1:2:4 concrete. "Ponding" had the highest average compressive strength, followed by "wet-covering" and the cube with least average compressive strength was "sprinkling."

Table 5: Twenty-Eight Day Compressive Strength

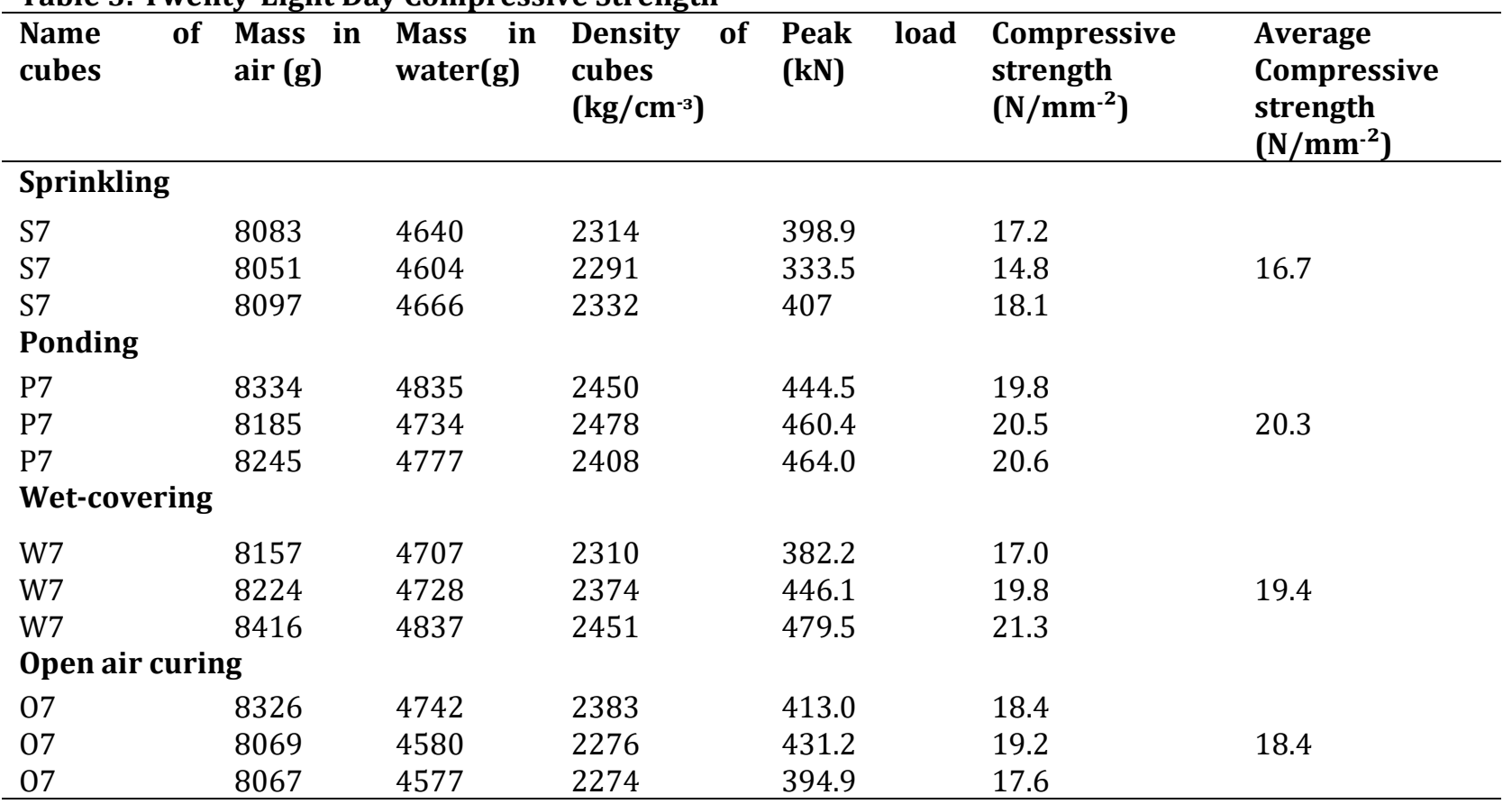




\section{Journal of Social and Development Sciences (ISSN 2221-1152)}

Vol. 10, No. 3, pp. 30-38, September 2019

Table 6 shows the seven (7) day compressive strength test result for 1:3:6 concrete. "Ponding" had the highest average compressive strength, followed by "wet-covering" and the cube with least average compressive strength was "sprinkling."

Table 6: Seven Day Compressive Strength

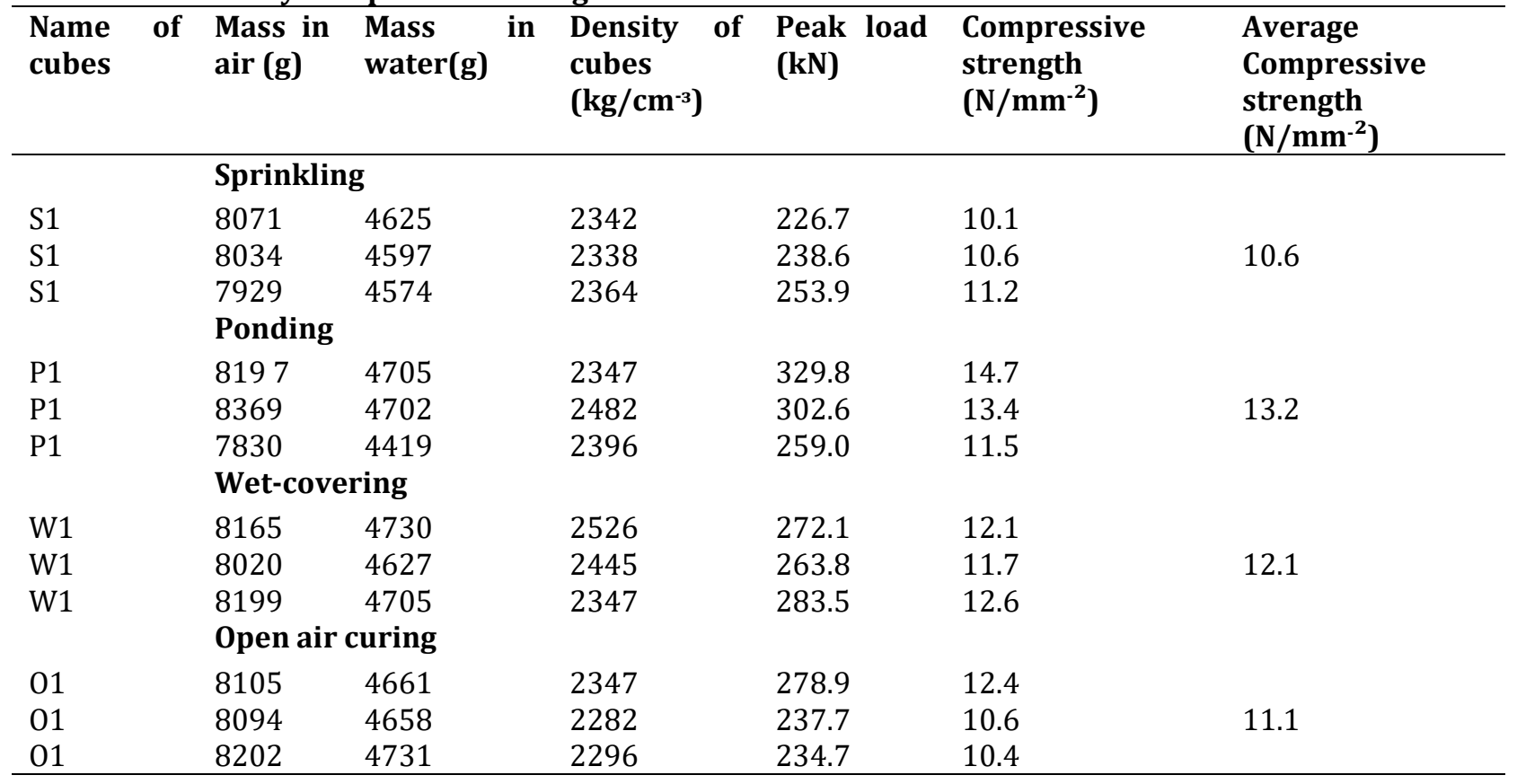

Table 7 shows the fourteen (14) day compressive strength test result for 1:3:6 concrete. "Ponding" had the highest average compressive strength, followed by "sprinkling" and the cube with least average compressive strength was "open air curing."

Table 7: Fourteen Day Compressive Strength

\begin{tabular}{|c|c|c|c|c|c|c|}
\hline $\begin{array}{l}\text { Name of } \\
\text { cubes }\end{array}$ & $\begin{array}{l}\text { Mass in } \\
\text { air (g) }\end{array}$ & $\begin{array}{l}\text { Mass in } \\
\text { water(g) }\end{array}$ & $\begin{array}{l}\text { Density of } \\
\text { cubes }\left(\mathrm{kg} / \mathrm{cm}^{-}\right. \\
\text {3) }\end{array}$ & $\begin{array}{l}\text { Peak load } \\
(k N)\end{array}$ & $\begin{array}{l}\text { Compressive } \\
\text { strength } \\
\left(\mathrm{N} / \mathbf{m m}^{-2}\right)\end{array}$ & $\begin{array}{l}\text { Average } \\
\text { Compressive } \\
\text { strength } \\
\left(\mathrm{N} / \mathrm{mm}^{-2}\right)\end{array}$ \\
\hline & \multicolumn{5}{|l|}{ Sprinkling } & \multirow{4}{*}{13.7} \\
\hline S5 & 8211 & 4693 & 2436 & 346.3 & 15.4 & \\
\hline S5 & 8191 & 4739 & 2471 & 311.1 & 13.8 & \\
\hline S5 & $\begin{array}{l}8324 \\
\text { Ponding }\end{array}$ & 4785 & 2907 & 264.7 & 11.8 & \\
\hline P5 & 8249 & 4734 & 3467 & 317.5 & 14.1 & \multirow{3}{*}{13.9} \\
\hline P5 & 7834 & 4448 & 2966 & 328.3 & 14.6 & \\
\hline \multirow[t]{2}{*}{ P5 } & 7600 & 4320 & 2186 & 293.4 & 13.0 & \\
\hline & \multicolumn{5}{|c|}{ Wet-covering } & \multirow{5}{*}{12.8} \\
\hline W5 & 801 & 4620 & 2383 & 272.0 & 12.1 & \\
\hline W5 & 8556 & 4957 & 2650 & 294.5 & 13.1 & \\
\hline \multirow[t]{2}{*}{ W5 } & 8117 & 4812 & 2528 & 299.8 & 13.2 & \\
\hline & Open air cl & uring & & & & \\
\hline 05 & 8267 & 4720 & 2456 & 262.0 & 11.6 & \multirow{3}{*}{12.5} \\
\hline 05 & 7628 & 4348 & 2203 & 277.0 & 12.3 & \\
\hline 05 & 8188 & 4682 & 2428 & 308.1 & 13.7 & \\
\hline
\end{tabular}


Table 8 shows the twenty-eight (28) day compressive strength test result for 1:3:6 concrete. Ponding" had the highest average compressive strength, followed by "sprinkling" and the cube with least average compressive strength was "open air curing."

Table 8: Twenty-Eight Day Compressive Strength Test Results

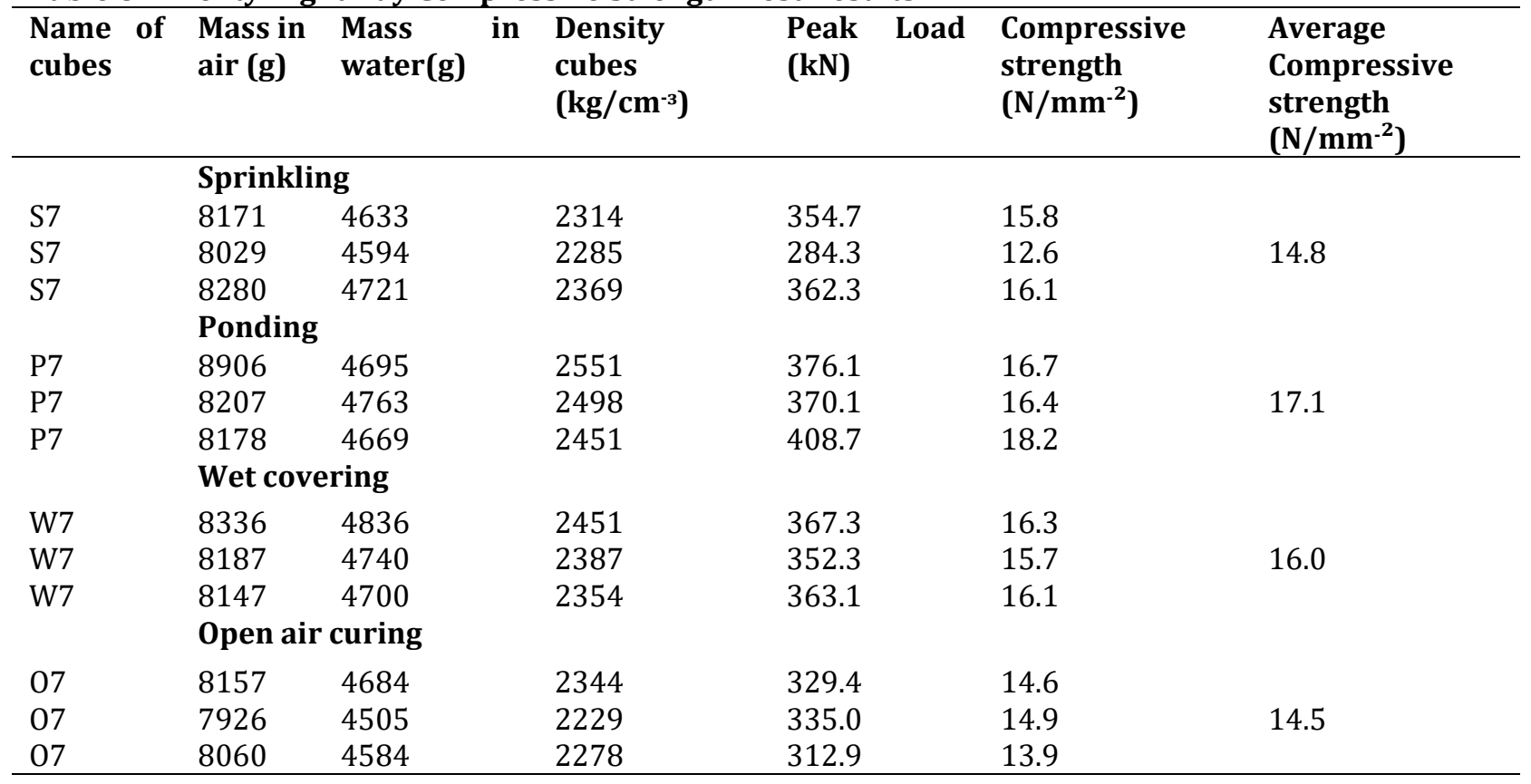

The 1:2:4 concrete cured during the $7^{\text {th }}$ day, by ponding method had the highest compressive strength with the least compressive strength recorded from open air curing. The strength development continued in the $14^{\text {th }}$ day under all curing conditions with the ponding method still maintaining the highest value of compressive strength. Sprinkling curing recorded the least value of strength which was in contrast to Raheem et al. (2013) who had ponding and open air curing recording highest value of compression on the $7^{\text {th }}$ and $14^{\text {th }}$ day of testing respectively and spray curing having least compressive on the $1^{\text {st }}$ and $2^{\text {nd }}$ week of testing. On the $28^{\text {th }}$ day, concrete cured by ponding method again had the highest compressive strength, but fell short of $25 \mathrm{~N} / \mathrm{mm}^{2}$ of equal ratio. Yanusa as cited in Anum et al. (2014) and M20 according to IS: 456 (2000) whereas the least strength was again recorded by sprinkling method. Yanusa as cited in Anum et al. (2014) accorded 1:3:6 ratio with a compressive strength $15 \mathrm{~N} / \mathrm{mm}^{2}$ whereas IS: 456 (2000) also prescribed a compressive strength of M10 after 28 days of curing and testing. All the curing methods recorded a strength values that are more than the standards. Concrete cured by ponding method had the highest compressive strength. On the $14^{\text {th }}$ day, concrete cured by ponding method had the highest compressive strength, as the least was open air curing, whiles on the $28^{\text {th }}$ day concrete cured by ponding method had the highest compressive strength and the open air curing recording the least strength.

Summary of Findings: The compressive strength of concrete from all the respective curing methods of ponding, sprinkling and open-air and wet covering for the mix ratio of 1:2:4 and 1:3:6 all exhibited increase in strength from the $7^{\text {th }}$ day to the $28^{\text {th }}$ day of crushing. Ponding method of curing recorded a highest strength development on the $7^{\text {th }}$ day of testing for the various mix ratios but increased $3 \mathrm{~N} / \mathrm{mm}^{2}$ after the $28^{\text {th }}$ day crushing for $1: 2: 4$ ratio and $3.9 \mathrm{~N} / \mathrm{mm}^{2}$ for the 1:3:6 ratio. Open-air curing method also recorded a difference of $5.5 \mathrm{~N} / \mathrm{mm}^{2}$ and $3.4 \mathrm{~N} / \mathrm{mm}^{2}$, whiles wet covering method recorded $5.8 \mathrm{~N} / \mathrm{mm}^{2}$ and $3.9 \mathrm{~N} / \mathrm{mm}^{2}$ and sprinkling method recording $2.1 \mathrm{~N} / \mathrm{mm}^{2}$ and $4.8 \mathrm{~N} / \mathrm{mm}^{2}$ respectively. "Ponding method" of curing produced the highest compressive strength for both 1:2:4 concrete and 1:3:6 concrete during the $28^{\text {th }}$ day of curing. Irrespective of curing method, the strength of concrete increased with age. 


\section{Conclusion and Recommendations}

The study examined the compressive strength of concrete using different curing methods. In conclusion, concrete cured by "ponding method" produced the desired strength, it gained adequate early strength as there was sufficient water around it to facilitate the necessary chemical reaction of the binding agent for it strength development. Sprinkling, wet-covering and the open-air methods on the other hand had an unsatisfactory strength for the1:2:4, ratio for the $28^{\text {th }}$ strength but satisfied IS standard with the 1:3:6 strength. Sprinkling method of curing should be applicable for areas where there is availability of water, since large volume of water is required. "Wet covering method" should be applicable for structural elements, such as columns, beams and slabs. Despite "ponding method" having the highest compressive strength of concrete, it is practically impossible to use "ponding method" to cure above ground structural elements.

Further Research: Further research should be conducted different mix ratios of concrete and same water cement ratio or one of the same mix ratio with two different water cement ratio to compare their respective strengths.

\section{References}

Al-Gahtani, A. S. (2010). Effect of curing methods on the properties of plain and blended cement concretes, Construction and Building Materials, 24(3), 308-314.

Anum, I., Williams, F. N. \& Adole, A. M. (2014). Properties of different grades of concrete using mix design method.

Bediako, M., Kevern, J. \& Amankwah, E. (2015). Effect of Curing Environment on the Strength Properties of Cement and Cement Extenders. Materials Sciences and Applications, 6, 33-39.

Bingöl A. F. \& Tohumcu İ. (2013). Effects of different curing regimes on the compressive strength properties of self-compacting concrete incorporating fly ash and silica fume, Materials \& Design, 51, 12-18.

BS, 1881. (1992). Method for determination of density of partially compacted semi-dry fresh concrete, part 3, British Standards Institution.

BS, 1881-102. (1983). Methods of testing concrete. Method for determination of slump (AMD 6090) (AMD 6727).

BS, 812. (1985). Testing aggregates - Part 103: Methods for determination of particle size distribution Section 103.1- Sieve tests. British Standards Institution, London.

BS, 882. (1992). Specification for aggregates from natural sources for concrete. British Standards Institution, London.

Bushlaibi, A. B. (2004). Effects of environment and curing methods on the compressive strength of silica fume high-strength concrete, Advances in Cement Research, 16(1), 17-22.

Ferreira, L., de Brito, J. \& Saikia, N. (2012). Influence of curing conditions on the mechanical performance of concrete containing recycled plastic aggregate, Construction and Building Materials, 36, 196-204.

Fonseca, N., de Brito, J. \& Evangelista, L. (2011). The influence of curing conditions on the mechanical performance of concrete made with recycled concrete waste, Cement and Concrete Composites, 33(6), 637-643.

Goel, A., Narwal, J., Verma, V., Sharma, D. \& Singh, B. (2013). Comparative Study on the Effect of Curing on The Strength of Concrete, International Journal of Engineering and Advanced Technology (IJEAT), 2 (6), 401-406.

IS, 456. (2000). Plain and Reinforced Concrete-Code of Practice-Bureau of Indian Standards, New Delhi.

Jackson, E. N. \& Akomah, B. B. (2018). Comparative Analysis of the Strength of Concrete with different Curing Methods in Ghana. The International Journal of Engineering and Science (IJES), 7(9), 39-44

Jackson, E. N., Mustapha, Z. \& Kotey, S. (2019). Compressive Strength of Concrete Produced with Proportions of Coconut and Palm Kernel Shells. International Journal of Architecture, Engineering and Construction, 8(1), 35-41.

Ling, I. H. \& Teo, D. C. L. (2011). Properties of EPS RHA lightweight concrete bricks under different curing conditions, Construction and Building Materials, 25(8), 3648-3655.

Mohamed, H. A. (2011). Effect of fly ash and silica fume on compressive strength of self-compacting concrete under different curing conditions, Ain Shams Engineering Journal, 2, 79-86. 


\section{Journal of Social and Development Sciences (ISSN 2221-1152)}

Vol. 10, No. 3, pp. 30-38, September 2019

Nahata, Y., Kholia, N. \& Tank, T. (2014). Effect of curing methods on efficiency of curing of cement mortar, APCBEE Procedia, 9, 222-229.

Neville, A. M. (2010). Properties of concrete, Longman Group Ltd, England.

Ogah, O. (2016). Effect of Curing Methods on the Compressive Strength of Concrete, International Journal of Advanced Trends in Computer Science and Engineering.

Olanitori, L. M. (2012). Cost Implication of Mitigating the Effect of Clay/Silt Content of Sand on Concrete, Compressive Strength. J. Civil Eng. Urban, 2(4), 143-148.

Osama, M. and Omar, N. (2019). IOP Conf. Ser.: Mater. Sci. Eng. 471032059.

Padhi, S. (2014). 6 Methods of curing concrete.

Raheem, A. A., Soyingbe, A. A. \& Emenike, A. J. (2013). Effect of curing methods on density and compressive strength of concrete. International Journal of Applied Science and Technology, 3(4).

Raheem, A. A., Soyingbe, A. A. \& Emenike, A. J. (2013). Effect of curing methods on density and compressive strength of concrete. International Journal of Applied Science and Technology, 3(4), 55-64.

Shih-Wei, C. (2013). Effect of Silt Fines on the Durability Properties of Concrete, Journal of Applied Science and Engineering, 16(4), 425-430.

Silva, R., de Brito, J. \& Saikia, N. (2013). Influence of curing conditions on the durability-related performance of concrete made with selected plastic waste aggregates. Cement and Concrete Composites, 35(1), 2331.

Surana, S., Pillai, R. \& Santhanam. (2017). Performance evaluation of field curing methods using durability index tests. Indian Concrete Journal, 91.

Teo, D. C. L., Mannan, M. A. \& Kurian, V. J. (2010). Durability of lightweight OPS concrete under different curing conditions. Mater Struct, 43(1).

Tijani, A. M. \& Mustapha, Z. (2017). Compressive Strength of Concrete Based on Laterite and Sea Sand Mixture. International Journal of Architecture, Engineering and Construction, 6(4), 44-49.

Velosa A. L. \& Cachim P. B. (2009). Hydraulic-lime based concrete: Strength development using a pozzolanic addition and different curing conditions, Construction and Building Materials, 23(5), 2107-2111.

YazicI, H., Yardımcı, M. Y., Aydın, S. \& Karabulut, A. Ş. (2009). Mechanical properties of reactive powder concrete containing mineral admixtures under different curing regimes, Construction and Building Materials, 23(3), 1223-1231. 